\title{
Hypoglycaemia assessment tool (HAT) study: subanalysis of the Lebanese cohort
}

Mireille Amm, ${ }^{1}$ Mohamad Rawas, ${ }^{2}$ Zelia Francis, ${ }^{3}$ Maya Chehabeddine, ${ }^{2}$ Amal Chalfoun, ${ }^{4}$ Mazen El Akel ${ }^{4}$ and Marie Merheb ${ }^{5}$

${ }^{1}$ Faculty of Medicine, Holy Spirit University, Kaslik, Lebanon (Correspondence to: M. Amm: mireille_amm@hotmail.com). ${ }^{2}$ Department of Endocrinology, Rafik Hariri University Hospital, Beirut, Lebanon. ${ }^{3}$ Lebanese American University Rizk Hospital Medical Centre, Achrafieh, Lebanon. ${ }^{4}$ Medical Affairs, Novo Nordisk, Beirut, Lebanon. ${ }^{5}$ Department of Endocrinology, Mount Lebanon Hospital, Hazmieh, Lebanon.

\begin{abstract}
Background: Diabetic hypoglycaemia affects medication adherence, patients' productivity and quality of life. It is also associated with an increased risk of cardiovascular complications.

Aims: To examine the impact of hypoglycaemia in insulin-treated patients in the Lebanese cohort of the Hypoglycaemia Assessment Tool (HAT) study.

Methods: The HAT study was an observational study covering a 6-month retrospective and a 4-week prospective period in 24 countries including Lebanon. Data were collected using self-assessment questionnaires and patient diaries from 1158 invited lebanese patients, aged $\geq 18$ years, with type 1 or type 2 diabetes mellitus (T1DM/T2DM) treated with insulin for $>12$ months. The primary endpoint was the proportion of patients experiencing $\geq 1$ hypoglycaemic event during the 4-week follow-up period.

Results: After 4 weeks of follow-up, 177/225 [78.7\%; 95\% confidence interval (CI): 72.7-83.8] of patients with T1DM and 291/630 (46.2\%; 95\% CI: 42.2-50.2) patients with T2D experienced at least 1 hypoglycaemic event. Rates of nocturnal and severe hypoglycaemia were 10.7 (95\% CI: 9.1-12.3) and 13.2 (95\% CI: 11.5-14.9) events/patient-year for T1DM, and 3.3 (95\% CI: $2.8-3.8)$ and 4.2 events/patient-year (95\% CI: 3.6-4.8) for T2DM, respectively. Fear of hypoglycaemia was significantly associated with nocturnal and severe hypoglycaemia in both diabetes types $(\mathrm{P}<0.001)$.

Conclusion: The results suggest that the less-advanced healthcare systems in Lebanon are implicated in lower levels of patient knowledge about hypoglycaemia and related preventive measures. Treatment strategies and glycaemia goals should be individualized according to patient preference, medical benefits, and risk of hypoglycaemia.

Keywords: diabetes, hypoglycaemia, insulin, nocturnal hypoglycaemia, severe hypoglycaemia.

Citation: Amm M; Rawas M; Francis Z; Chehabeddine M; Chalfoun A; El Akel M et al. Hypoglycaemia Assessment Tool (HAT) study: subanalysis of the Lebanese cohort. East Mediterr Health J. 2020;26(8):939-947. https://doi.org/10.26719/emhj.20.037

Received: 17/05/18; accepted: 21/04/19

Copyright (c) World Health Organization (WHO) 2020. Open Access. Some rights reserved. This work is available under the CC BY-NC-SA 3.0 IGO license (https://creativecommons.org/licenses/by-nc-sa/3.0/igo)
\end{abstract}

\section{Introduction}

Diabetes is a worldwide health problem associated with serious morbidity, mortality, and considerable economic burdens (1). The prevalence of type 2 diabetes mellitus (T2DM) in Lebanon was reported to be high (8.5\%) between 2008 and 2009 (2), including many Lebanese patients who were not adequately controlled or followed up according to the International Diabetes Management Practices Study (3). As reported in that study, $22.6 \%$ of the Lebanese patients were treated with insulin; most commonly basal insulin alone followed by premix insulin alone.

Insulin is the cornerstone of therapy for patients with type 1 diabetes mellitus (T1DM) and it is among the major therapeutic classes recommended for treating type 2 DM (T2DM). However, different studies have shown an association between insulin therapy and increased risk of hypoglycaemia $(4,5)$, in which $25-30 \%$ of insulin-treated patients with diabetes had 1 or more severe hypoglycaemic episodes every year (6). The Diabetes Complications and Controls Trial found that intensive therapy in patients with T1DM caused a 3 -fold increase in the number of hypoglycaemic events, compared with those treated less aggressively (7). Hypoglycaemia is a common adverse effect of insulin (8), and is a hindrance to achieving treatment goals in T1DM and T2DM $(4,9)$. This has driven the American Diabetes Association (ADA) Standards of Medical Care in Diabetes - 2017 to recommend a lessstringent, glycated haemoglobin (HbAic) goal of $<8 \%$ in patients with a history of severe hypoglycaemia (10).

Hypoglycaemia affects medication adherence, patients' productivity (11), and quality of life at the mental, physical and social functioning levels (12). It also places a heavy burden on healthcare systems (12). Pai-Feng Hsu et al. showed that clinically severe or mild hypoglycaemia is associated with an increased risk of cardiovascular events, all-cause hospitalization, and all-cause mortality (13). Various studies have reported that hypoglycaemia is associated with higher risks of cardiovascular complications (14-16).

Data available from clinical trials are not enough to address the problem of hypoglycaemia. Also, lack of real- 
world data on hypoglycaemia in Lebanon necessitates the conduct of a large-scale study to assess the problem of hypoglycaemia in terms of rates, risk factors, and atrisk patients, and utilizing these data in clinical practice. The aim of the Hypoglycaemia Assessment Tool (HAT) study was to examine the impact of hypoglycaemia in an insulin-using global patient population (which includes the Lebanese cohort) in an epidemiological observational study covering a 6-month retrospective and 4-week prospective time periods.

\section{Methods}

\section{Study design and ethical considerations}

This study was a noninterventional, multicentre, 4-week cohort survey of hypoglycaemic events conducted across 2004 sites in 24 countries (Argentina, Austria, Bulgaria, Canada, Croatia, Czech Republic, Denmark, Finland, Germany, Hungary, India, Israel, Lebanon, Malaysia, Mexico, Netherlands, Poland, Romania, Russian Federation, Saudi Arabia, Serbia, Slovakia, Slovenia, and Sweden) from 2012 to 2013 in a staggered fashion (start time varied by country). The same protocol was followed across all participating countries. The study used self-assessment questionnaires (SAQs) and patient diaries where all study materials were translated into local languages and collected data were translated into English for analysis. The study protocol and assessments were conducted in accordance with the Declaration of Helsinki (2004) and the International Conference on Harmonisation Guidelines for Good Clinical Practice (1996), and approved by country-specific regulatory agencies and ethics committees. Informed consent was obtained from all individual participants included in the study.

\section{Study population}

Inclusion criteria consisted of patients with T1DM or T2DM, aged $\geq 18$ years, being treated with insulin for $>12$ months, and who had given informed consent to participate in the study. Nonambulatory patients, illiterate patients and patients unable to complete a written survey were excluded. Eligible patients were enrolled consecutively during a routinely scheduled clinical consultation with their healthcare provider.

\section{Ethical approval and consent to participate}

The study protocol and assessments were conducted in accordance with the Declaration of Helsinki (2004) and the International Conference on Harmonisation Guidelines for Good Clinical Practice (1996), and approved by country-specific regulatory agencies and ethics committees. Informed consent was obtained from all individual participants included in the study.

\section{Study endpoints}

The primary endpoint was to determine the proportion of patients experiencing at least 1 hypoglycaemic event during the 4-week follow-up period. Secondary endpoints included: hypoglycaemia rates, HbAlc level at baseline, relationship between HbAlc and hypoglycaemia, including proportion of patients with $\mathrm{HbAlc}<7.0 \%$ (53 mmol/l) and $>9.0 \%(75 \mathrm{mmol} / \mathrm{l})$ with or without hypoglycaemia, and relationship between hypoglycaemia and factors such as age, fear of hypoglycaemia, disease duration and duration of insulin use.

\section{Assessments}

This study was based on a 2-part SAQ. Part 1 was introduced upon patient entry and it recorded baseline demographics, treatment information, as well as history of severe hypoglycaemia over the last 6 months and nonsevere hypoglycaemia over the previous 4 weeks. Part 2 was completed 4 weeks after baseline visit and recorded the occurrence of both severe and nonsevere hypoglycaemia during these 4 weeks. In order to improve patients' recall, they were provided with a diary, which was also used to record hypoglycaemic events. If a patient recorded more hypoglycaemic events using the patient diary than the SAQ Part 2, the patient diary value was used to calculate prevalence of hypoglycaemia in the 4 weeks after baseline.

\section{Hypoglycaemia classification}

Nonsevere hypoglycaemia was defined as an event managed by patients alone; severe hypoglycaemia was defined based on the ADA definition, as any hypoglycaemic event requiring assistance of another person to administer carbohydrate, glucagon or other resuscitative actions (17); and nocturnal hypoglycaemia was defined as any event occurring between midnight and o6:0o hours. These 3 categories of hypoglycaemia were included in the SAQ and the patient diary. Combined measures of hypoglycaemia refer to the sum of all individual hypoglycaemic events, and were calculated based on data collected from the patient diary and questionnaire.

\section{Sample size and statistical analyses}

To calculate the percentage of patients experiencing a hypoglycaemic event with a 95\% confidence interval (CI) precision, a sample size of approximately 12000 patients was selected. Taking into consideration a $37 \%$ response rate in SAQ Part 2, the total number of patients was estimated to be around 32 ooo. In Lebanon, 1158 patients were invited to participate in the study based on convenience sampling, accounting thus for $3.6 \%$ of the overall study cohort.

For the primary endpoint, the percentage of patients experiencing any hypoglycaemia during the 4-week follow-up period was calculated along with its 95\% CI. For the secondary endpoints of severe or nocturnal hypoglycaemic events, the number and proportion of patients having an event, number of events, follow-up time (patient-years), estimated hypoglycaemia rate with corresponding $95 \% \mathrm{CI}$, and number of patients missing were reported for the 4 weeks after baseline.

Univariate negative binomial regression models were used to examine the relationship between hypoglycaemia and the following factors: age; sex; HbAlc in Mmol/mol 
and percentage; duration of diabetes in years; duration of insulin therapy in years; type of insulin therapy; frequency of blood glucose testing in average number of checks per day; knowledge of hypoglycaemia (i.e., knowing what hypoglycaemia is before reading the definition in the SAQ introduction); fear of hypoglycaemia; study period (prospective/retrospective); and diabetes type. These models were based on the complete analysis set (patients who completed SAQ Part 2) and were stratified by country, specifying a log-transformed exposure time offset term and adjusted for all variables in the model. The statistical significance was two-sided and set at $P<$ 0.05 .

All other variables are presented descriptively only, with the mean and 95\% CI being presented. No imputation of missing data was performed.

\section{Results}

\section{Population characteristics}

Out of 1158 patients invited to participate in the study, 905 (78.2\%) (250 with T1DM and 655 with T2DM) were recruited and completed SAQ Part 1. Out of those recruited, 851 patients (94\%) (222 with T1DM and 629 with T2DM) completed SAQ Part 2 and 837 patients (92.5\%) (224 with T1DM and 613 with T2DM) completed the patient diary. All patients were followed up by endocrinologists.

Both types of diabetes were almost equally distributed among the sexes (male/female: $54.2 / 45.8 \%$ with T1DM vs $48 / 52 \%$ with $\mathrm{T} 2 \mathrm{DM})$. Patients with $\mathrm{T} 2 \mathrm{DM}$ were older (60.5 \pm 11.0 years) than those with $\mathrm{T} 1 \mathrm{DM}$ ( $35.2 \pm 15.9$ years) and had a longer disease duration ( $14.6 \pm 8.0$ years vs 12.8 \pm 8 .8 years, respectively). As expected, T1DM patients were using insulin for a longer period than T2DM patients were (11. $8 \pm 8.7$ years vs $5 \pm 4.1$ years). Mean HbAic levels and percentage were almost similar in T1DM and T2DM patients $[63.8 \pm 17.6 \mathrm{Mmol} / \mathrm{mol}(8 \%)$ vs $68.4 \pm 17.2 \mathrm{mmol} /$ mol (8.4\%), respectively]. Most patients checked blood sugar levels [T1DM, 97.6\% $(n=241) ; \mathrm{T} 2 \mathrm{DM}, 90.5 \%(n=$ 588)] and reported experiencing at least 1 hypoglycaemic event [T1DM, 91\% $(n=223) ;$ T2DM, $80.3 \%(n=521)]$.

\section{Reporting of hypoglycaemia}

After 4 weeks of follow-up, among 225 TiDM patients, 177 experienced at least 1 hypoglycaemic event $(78.7 \%$; $95 \%$ CI: 72.7-83.8\%); 70 experienced severe hypoglycaemia (31.1\%; 95\% CI: 25.1-37.6\%); 167 experienced nonsevere hypoglycaemia (74.2\%, 95\% CI: $68.0-79.8 \%$ ); and 90 experienced nocturnal hypoglycaemia (41.5\%; 95\% CI: $34.8-48.3 \%$ ). Among 630 T2DM patients, 291 experienced at least 1 hypoglycaemic event (46.2\%; 95\% CI: 42.2-50.2\%); 92 experienced severe hypoglycaemia (14.6\%, 95\% CI: 11.9-17.6\%); 269 experienced nonsevere hypoglycaemia $(42.8 \%, 95 \%$ CI: 38.9-46.7\%); and 101 experienced nocturnal hypoglycaemia (16.3\%; 95\% CI: 13.5-19.5\%). The estimated annual incidence rate of hypoglycaemic events requiring hospital admission at 4 weeks after baseline was 5.5\% (95\% CI: $2.9-9.4 \%$ ) for patients with TiDM and $2.4 \%$ (95\% CI: 1.3-3.9\%) for patients with T2DM.
The estimated annual rate of any hypoglycaemic event was 73.7 (95\% CI: 69.6-77.8) and 18.1 (95\% CI: 16.919.3) events/patient-years for patients with T1DM and T2DM, respectively. For nonsevere hypoglycaemia, the estimated annual rate was 60.5 (95\% CI: 56.9-64.3) and 13.9 (95\% CI: 12.8-15.0) events/patient-years for patients with T1DM and T2DM, respectively. For nocturnal hypoglycaemia, the estimated annual rate was 10.7 (95\% CI: 9.1-12.3) and 3.3 events/patient-years (95\% CI: 2.8-3.8) for patients with T1DM and T2DM, respectively. For severe hypoglycaemia, the estimated annual rate was 13.2 (95\% CI: 11.5-14.9) and 4.2 events/patient-years (95\% CI: 3.6-4.8) for patients with T1DM and T2DM, respectively. The estimated annual incidence rate of hypoglycaemic events requiring hospital admission at 4 weeks after baseline was 0.8 (95\% CI: 0.4-1.3) for patients with T1DM and 0.3 (95\% CI: 0.2-0.5) for patients with T2DM.

\section{Factor associated with hypoglycaemia}

The relationship between any, nocturnal or severe hypoglycaemia and age, HbAic, duration of diabetes, duration of insulin use, and fear of hypoglycaemia (as indicated on a 10-point scale) was studied using fully adjusted negative binomial modelling. Older age of patients with either type of DM was significantly associated with a reduced risk of any hypoglycaemia $(P<0.001)$ and nocturnal hypoglycaemia $(P=0.001$ ) (Figure 1). As fear of hypoglycaemia increased, the risk of any hypoglycaemia $(P=0.014)$ and nocturnal hypoglycaemia $(P<0.001)$ increased significantly. Similarly, fear of hypoglycaemia was significantly associated with severe hypoglycaemia in both T1DM and T2DM patients $(P<0.001)$. Among 52 T1DM patients and 75 T2DM patients with HbAlc $<7 \%$ at baseline, 44 (84.6\%) and $35(46.7 \%)$ had any hypoglycaemia in the 4 weeks after baseline, respectively. The association between different baseline levels of HbAlc and proportion of patients with any hypoglycaemia is shown in Figure 2.

\section{Discussion}

The aim of our study was to determine the percentage of insulin-treated patients with T1DM or T2DM experiencing at least 1 hypoglycaemic event during a 4-week observational period, and to study the relationship between hypoglycaemia and other factors. Among T1DM patients, the prevalence of any, severe and nocturnal hypoglycaemia was $78 \%, 31 \%$ and $41 \%$, respectively. In the Diabetes Complications and Controls Trial, the annual prevalence of severe hypoglycaemia was $36 \%(18,19)$. In our study, the reported prevalence of severe hypoglycaemia among T1DM patients was within the range of $30-40 \%$ reported in other studies (20-23).

Among TiDM patients, the estimated annual rates were $73.7,13.2$ and 10.7 events/patient-year for any, severe and nocturnal hypoglycaemia, respectively. The estimated annual rate of severe hypoglycaemia was considerably greater than in other studies (0.7-1.59 episodes/patient-year) $(24,25)$. Two studies done in the United Kingdom of Great Britain and Northern Ireland (UK) reported a severe hypoglycaemia rate of 1.15-3.2 
Figure 1 Fully adjusted negative binomial modelling of the associations between patient characteristics and incidence rate ratios for (A) any, (B) severe or (C) nocturnal hypoglycaemia $(n=680)$.
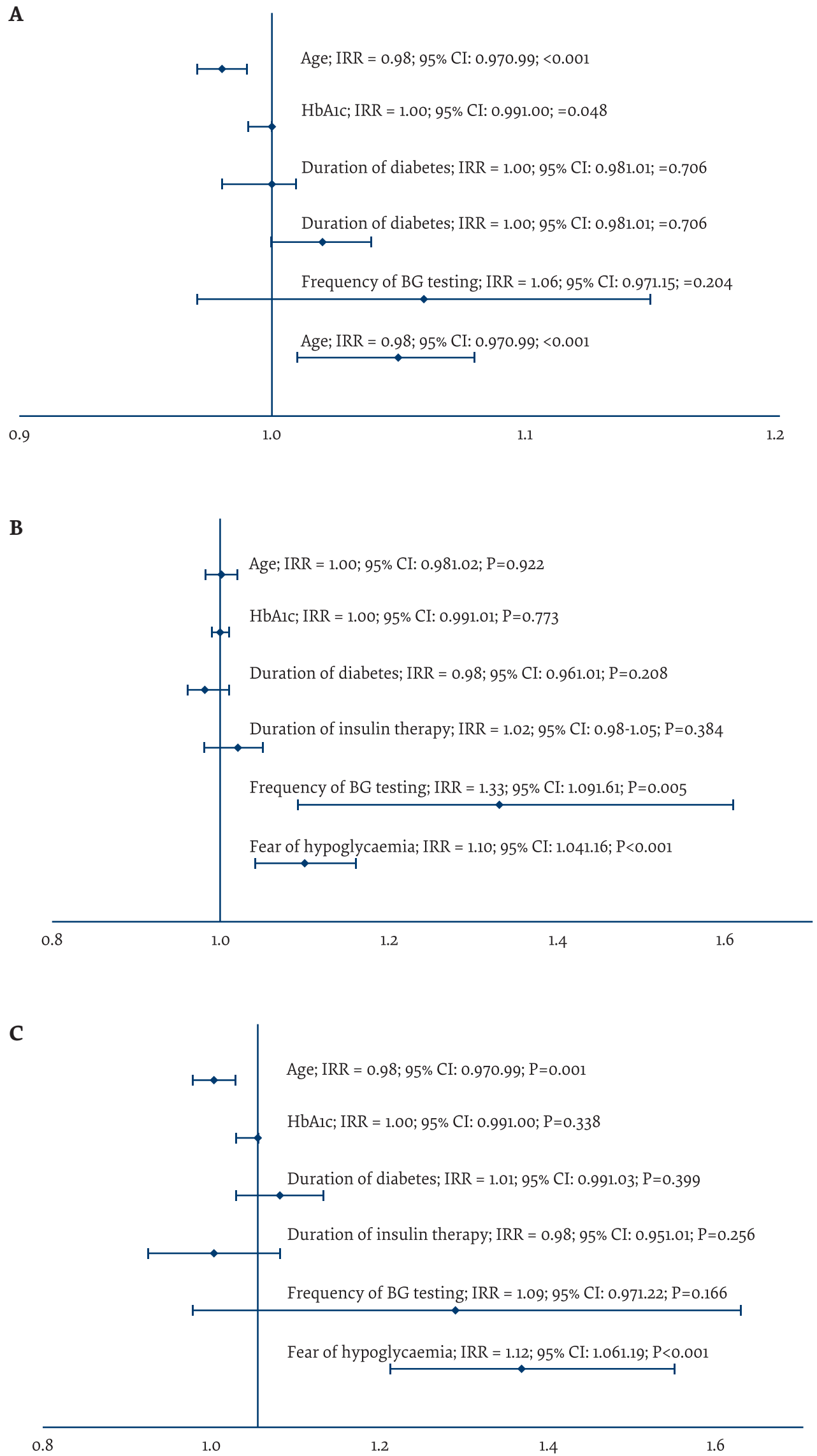

$B G=$ blood glucose $; C I=$ confidence interval; HbAlc = glycated haemoglobin; $I R R=$ incidence rate ratio. 
events/patient-year $(23,26)$. A recent study involving 7 European countries (25) reported a rate of nocturnal hypoglycaemia among T1DM patients almost double (20 events/patient-year) that reported in our study.

Among T2DM patients, the prevalence of any, severe and nocturnal hypoglycaemia was $46 \%, 14.6 \%$ and $16.3 \%$, respectively. The estimated annual rates were 18.1, 4.2 and 3.3 events/patient-year for any, severe and nocturnal hypoglycaemia, respectively. A recent meta-analysis of population-based studies reported that the prevalence of severe hypoglycaemia was $21 \%$ among insulin-using patients (27). The UK Hypoglycaemia Study reported mild hypoglycaemia rates of 10.2 events/patient-year and severe hypoglycaemia rates of 0.7 events/patientyear in patients with T2DM using insulin for > 5 years (23). Systematic reviews considering hypoglycaemia prevalence in randomized controlled trials involving patients with T2DM (28-31) reported that severe hypoglycaemia prevalence was $<1 \%$, which is substantially lower than our findings. In the Veterans Affairs Diabetes Trial involving T2DM patients, rates of any symptomatic hypoglycaemic episode were 383-1333 per 100 patientyears, whereas rates of severe hypoglycaemia were 3-9 per 100 patient-years (5). However, these differences should be carefully interpreted taking into consideration the aspects of randomized controlled trials as they do not often reflect real-life situations. The estimated annual rate of nocturnal hypoglycaemia in T2DM patients falls within the range (0.2-13.4 events/patient-year) reported in a study by Elliott et al. (32).

The rate of hypoglycaemia was expected to be higher in T1DM than in T2DM. This can be explained in the context of different treatment strategies for both types of diabetes and different pathophysiology. In parallel, the counter-regulatory physiological defences against hypoglycaemia (decreases in insulin and increases in glucagon) are impaired in patients with diabetes with beta-cell failure. This failure is absolute in T1DM and more gradual in T2DM.

The higher rates of hypoglycaemia in both types of diabetes reported by our study can be explained differently. First, endocrinologists in Lebanon have low awareness on hypoglycaemia. Indeed, these specialists do not educate their patients about the risk of hypoglycaemia with insulin use, leading to lower levels of patients' knowledge about hypoglycaemia and related preventive measures. These observations reflect a less-advanced Lebanese healthcare system. Second, poor medical follow-up can result in higher rates of hypoglycaemia. A study done by Costanian et al. on the prevalence, correlates and management of T2DM in Lebanon found that adherence to management and self-care measures was suboptimal, resulting in high complication rates (2). Additionally, although the rate of glucose self-monitoring in the study was high $(97.6 \%$ in T1DM and $90.5 \%$ in T2DM), the level of self-care was not adequate. Indeed, the patients were not aware of the risk of hypoglycaemia but were aware of hyperglycaemia, and frequent self-care is done to monitor hyperglycaemia rather than hypoglycaemia.

Although the results of the present study were lower or comparable to other findings, the impact of nocturnal hypoglycaemia should not be underestimated. Episodes of nocturnal hypoglycaemia may have been under-reported and undetected as patients may be unaware of such an event (32), because symptoms are

Figure 2 Percentage of patients reporting hypoglycaemia during the prospective period stratified by baseline glycated haemoglobin level for patients with T1DM and T2DM.

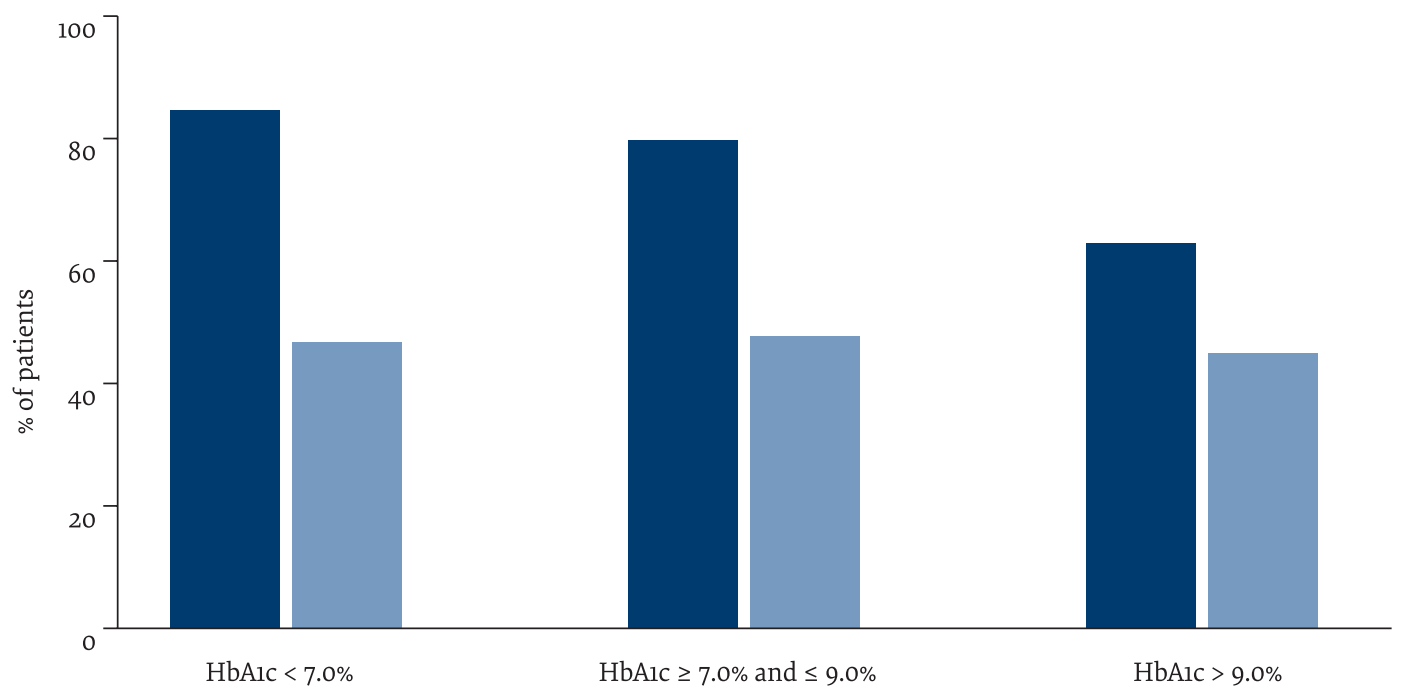

$\operatorname{T1DM}(\mathrm{N}=225)$

$\operatorname{T} 2 \mathrm{DM}(\mathrm{N}=630)$ 
absent during sleeping and glucose monitoring is rarely done at night (33). In T1DM patients, around 50\% of all sever hypoglycaemic events occur during sleeping $(18,34)$. Additionally, nocturnal hypoglycaemia affects patient's well-being and sleep duration and quality (35). Furthermore, sudden nocturnal death, also known as death-in-the-bed syndrome, is associated with nocturnal hypoglycaemia and contributes to $5-6 \%$ of all deaths among young patients with $\operatorname{T1DM}(36,37)$.

The rate of severe hypoglycaemia among patients with both types of DM was significantly high. Different studies have demonstrated that impaired awareness of hypoglycaemia is associated with higher rate of severe hypoglycaemia in T1DM (25) and T2DM (38). A recent large observational study reported an increased risk of mortality in the 12 months after a severe hypoglycaemic event (39). Moreover, neuroimaging has demonstrated transient cerebral deficits associated with neurological signs in patients who experience episodes of severe hypoglycaemia $(40,41)$. The Edinburgh Type 2 Diabetes study concluded that severe hypoglycaemia is associated with both poor initial cognitive ability and accelerated cognitive decline (42).

It has been shown that older patients are more vulnerable than younger patients to hypoglycaemia (43-45). This may be due to different comorbidity, polypharmacy, cognitive impairment, impairment in counter-regulatory hormone responses, and malnutrition $(43,46)$. In contrast to these previous studies, we found that older patients experienced lower rates of any and nocturnal hypoglycaemia. However, this may not reflect the reality as rates of hypoglycaemia are mainly under-reported in older patients. This is because such patients may be unfamiliar with the signs and symptoms of hypoglycaemia; loss of warning symptoms of hypoglycaemia (in older patients the threshold of autonomic symptoms of hypoglycaemia occurs at a lower blood glucose level); and cognitive impairment. In parallel, fear of hypoglycaemia was significantly associated with higher rates of any, severe and nocturnal hypoglycaemia. This is in line with the findings of a literature review that showed that patients' fear of future episodes causes them to suffer from anxiety and panic attacks that further increase the number of hypoglycaemic episodes (47). However, fear of hypoglycaemia may eventually lead to suboptimum insulin therapy and poor glycaemic control (47).

To our knowledge, this is the first observational study that addresses the impact of hypoglycaemia among Lebanese patients with DM. Our study involved both types of DM, allowing the comparison between these subgroups. In contrast to clinical trials and physicians' case reports, observational studies allow collection of a wide variety of related data that more or less reflect real-world practice. Thus, more accurate estimations are made. The simplicity of the questionnaires may have contributed to the high completion rate.

Several limitations to our study should be considered. First, data collected through questionnaires and selfreporting are usually subjected to recall bias. Although patient diaries were used in addition to the questionnaire to minimize recall bias, this step introduced some sort of overestimation of hypoglycaemia rates. Second, the short prospective duration may not reflect the fluctuations in hypoglycaemia rates throughout a whole year. Third, willingness to participate and local literacy rates were likely to have affected patients' participation. Furthermore, the observational nature of the study does not allow us to draw a causal relationship between hypoglycaemia and most of the included variables.

\section{Conclusion}

Further studies and analyses are required including a larger sample size for a longer prospective duration to detect the long-term impacts and associated complications of hypoglycaemia. Treatment strategies and glycaemia goals should be individualized according to patient preference, medical benefits, and risk of hypoglycaemia. Multidisciplinary integration among all healthcare providers is essential in educating patients about the definition of hypoglycaemia, associated substantial risks, treatment and preventive measures.

\section{Acknowledgement}

The authors acknowledge medical writing support provided by Racha Aaraj and Mohamed Yassine, from Phoenix Clinical Research, Lebanon.

Funding: Financial support for medical writing was provided by Novo Nordisk, Lebanon.

Competing interest: None declared. 


\section{Étude de l'outil d'évaluation de l'hypoglycémie : sous-analyse de la cohorte libanaise Résumé}

Contexte : L'hypoglycémie chez les patients diabétiques affecte leur observance thérapeutique, leur productivité et leur qualité de vie. Elle est également associée à un risque accru de complications cardio-vasculaires.

Objectifs : Examiner l'impact de l'hypoglycémie chez les patients traités par insuline dans la cohorte libanaise faisant partie de l'étude de l'outil d'évaluation de l'hypoglycémie.

Méthodes: L'étude de l'outil d'évaluation de l'hypoglycémie était une étude d'observation couvrant une période rétrospective de six mois et une période prospective de quatre semaines dans 24 pays, y compris le Liban. Les données ont été recueillies à l'aide de questionnaires d'auto-évaluation et des journaux de bord de 1158 patients libanais, âgés de 18 ans et plus, atteints de diabète sucré de type 1 ou 2 traités par insuline depuis plus de 12 mois, qui avaient été invités à participer à l'étude. Le principal critère d'évaluation était la proportion de patients ayant connu un épisode d'hypoglycémie ou plus pendant la période de suivi de quatre semaines.

Résultats : Après quatre semaines de suivi, 177 des 225 patients atteints de diabète sucré de type 1 [78,7 \% ; intervalle de confiance (IC) à $95 \%$ : 72,7-83,8] et 291 des 630 patients atteints de diabète sucré de type 2 (46,2 \%; IC à 95\% : 42.2-50.2) ont connu au moins un épisode d'hypoglycémie. Les taux d'hypoglycémie nocturne et sévère étaient respectivement de 10,7 (IC à $95 \%$ : 9,1-12,3) et 13,2 (IC à $95 \%$ : 11,5-14,9) épisodes/patient-année pour le diabète sucré de type 1, et de 3,3 (IC à $95 \%$ : 2,8-3,8) et 4,2 épisodes/patient-année (IC à 95\%:3,6-4,8) pour le diabète sucré de type 2 . La peur de l'hypoglycémie était associée de manière significative à une hypoglycémie nocturne et sévère dans les deux types de diabète $(p<0,001)$.

Conclusion : Les résultats indiquent que les systèmes de soins de santé moins avancés au Liban contribuent à la faible connaissance des patients en matière d'hypoglycémie ainsi que les mesures préventives qui y sont liées. Les stratégies de traitement et les objectifs en matière de glycémie doivent être individualisés en fonction des préférences du patient, des avantages médicaux et du risque d'hypoglycémie.

$$
\begin{aligned}
& \text { دراسة معنية بأداة تقييم نقص سكر الدم: تحليل فرعي لمجموعة أتر ابية من سكان لبنان } \\
& \text { مير اي عمّ، محمّد روّاس، زيليا فرنسيس، مايا شهاب الدين، أمل شلفون، مازن العاقل، ماري مرعب }
\end{aligned}
$$

الخلفية: يؤثر نقص السكر في الدم بسبب داء السُّكَّي على مدى الامت التثال للعلاج، وإنتاجية المريض، وجودة الحياة. كما يقترن أيضاً بزيادة خخاطر مضاعفات أمر اض القلب وألب الأوعية الدموية.

الأهداف: هدفت الدراسة إلى دراسة أثر نقص السكر في الدم في بحموعة أترابية من المرضى في لبنان من الذين يُعالجَّون بالأنسولين، وشملتهم الدراسة المعنية بأداة تقييم نقص الدراف السكر في الدم.

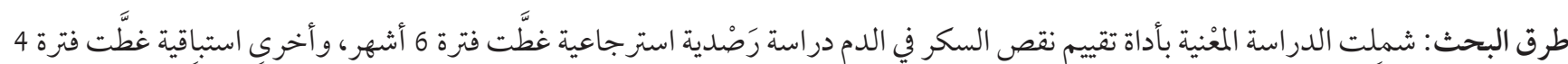

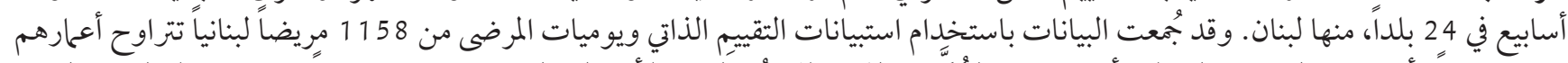

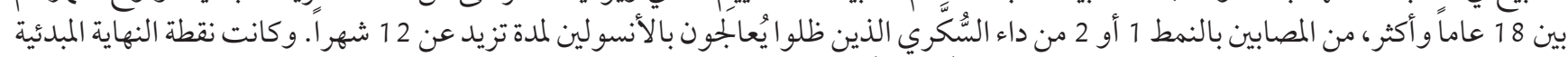

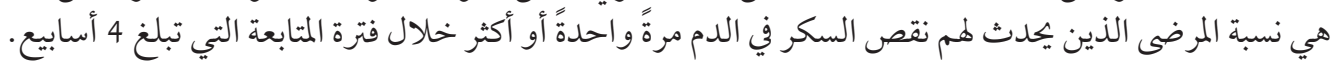

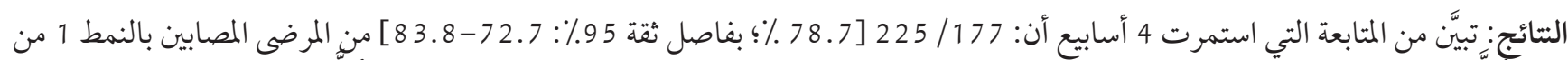

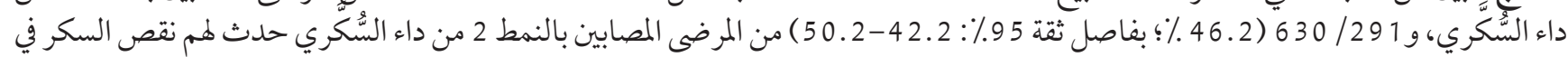

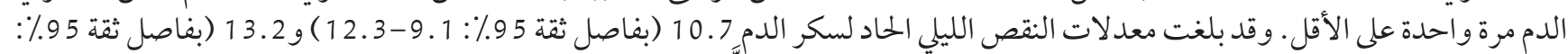

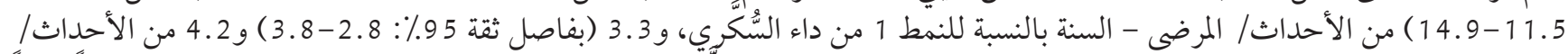

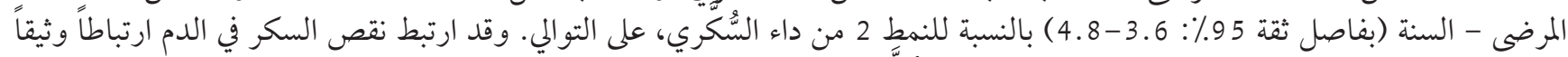

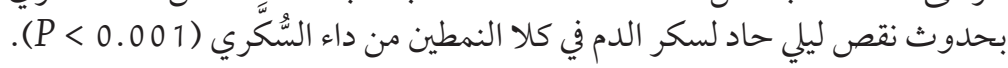

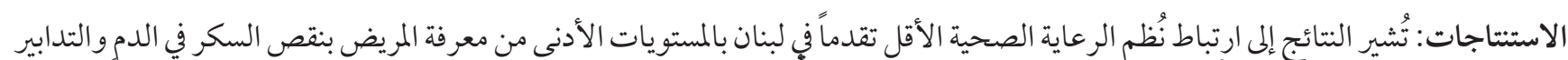

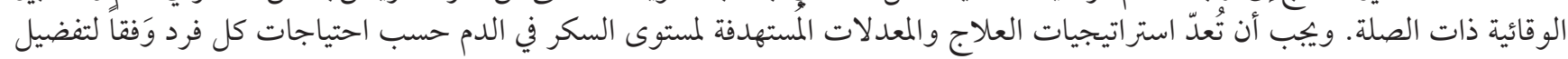

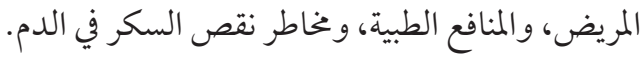




\section{References}

1. Roglic G, Unwin N, Bennett PH, Mathers C, Tuomilehto J, Nag S et al. The burden of mortality attributable to diabetes. Diabetes Care. 2005 Sep;28(9):2130-5. http://dx.doi.org/10.2337/diacare.28.9.2130 PMID:16123478

2. Costanian C, Bennett K, Hwalla N, Assaad S, Sibai AM. Prevalence, correlates and management of type 2 diabetes mellitus in Lebanon: findings from a national population-based study. Diabetes Res Clin Pract. 2014 Sep;105(3):408-15. http://dx.doi. org/10.1016/j.diabres.2014.06.005 PMID:25005850

3. Azar ST, Malha LP, Zantout MS, Naja M, Younes F, Sawaya MT. Management and control of patients with type 2 diabetes mellitus in Lebanon results from the International Diabetes Management Practices Study (IDMPS). J Med Liban. 2013 JulSep;61(3):127-31. http://dx.doi.org/10.12816/0001439 PMID:24422361

4. The Diabetes Control and Complications Trial Research Group. The effect of intensive treatment of diabetes on the development and progression of long-term complications in insulin-dependent diabetes mellitus. N Engl J Med. 1993 Sep 30;329(14):977-86. http://dx.doi.org/10.1056/NEJM199309303291401 PMID:8366922

5. Duckworth W, Abraira C, Moritz T, Reda D, Emanuele N, Reaven PD et al. Glucose control and vascular complications in veterans with type 2 diabetes. N Engl J Med. 2009 Jan 8;360(2):129-39. http://dx.doi.org/10.1056/NEJMoa0808431 PMID:19092145

6. Leese GP, Wang J, Broomhall J, Kelly P, Marsden A, Morrison W et al. Frequency of severe hypoglycemia requiring emergency treatment in type 1 and type 2 diabetes. Diabetes Care. 2003 Apr;26(4):1176-80. http://dx.doi.org/10.2337/diacare.26.4.1176 PMID:12663593

7. Nathan DM, DCCT/Edic Research Group. The diabetes control and complications trial/epidemiology of diabetes interventions and complications study at 30 years: overview. Diabetes Care. 2014;37(1):9-16. http://dx.doi.org/10.2337/dc13-2112 PMID:24356592

8. Kamal AD, Dixon AN, Bain SC. Safety and side effects of the insulin analogues. Expert Opin Drug Saf. 2006 Jan;5(1):131-43. http:// dx.doi.org/10.1517/14740338.5.1.131 PMID:16370962

9. Nathan DM. Diabetes Control and Complications Trial/Epidemiology of Diabetes Interventions and Complications (DCCT/ EDIC) Study Research Group. Intensive diabetes treatment and cardiovascular disease in patients with type 1 diabetes. NEJM. 2005 Dec 22; 353:2643-53. http://dx.doi.org/10.1056/NEJMoa052187 PMID:16371630

10. Marathe PH, Gao HX, Close KL. American Diabetes Association standards of medical care in diabetes 2017. J Diabetes. 2017 Apr;9(4):320-4. http://dx.doi.org/10.1111/1753-0407.12524 PMID:28070960

11. Lopez JM, Annunziata K, Bailey RA, Rupnow MF, Morisky DE. Impact of hypoglycemia on patients with type 2 diabetes mellitus and their quality of life, work productivity, and medication adherence. Patient Prefer Adherence. 2014 May 8;8:683. http://dx.doi. org/10.2147/PPA.S58813 PMID:24855344

12. Fidler C, Elmelund Christensen T, Gillard S. Hypoglycemia: an overview of fear of hypoglycemia, quality-of-life, and impact on costs. J Med Econ. 2011;14(5):646-55. http://dx.doi.org/10.3111/13696998.2011.610852 PMID:21854191

13. Hsu PF, Sung SH, Cheng HM, Yeh JS, Liu WL, Chan WL et al. Association of clinical symptomatic hypoglycemia with cardiovascular events and total mortality in type 2 diabetes. Diabetes Care. 2013 Apr;36(4):894-90o. http://dx.doi.org/10.2337/dc12-0916 PMID:23223349

14. Svensson AM, McGuire DK, Abrahamsson P, Dellborg M. Association between hyper-and hypoglycaemia and 2 year all-cause mortality risk in diabetic patients with acute coronary events. Eur Heart J. 2005 Jul;26(13):1255-61. http://dx.doi.org/10.1093/eurheartj/ehi230 PMID:15821004

15. Goyal A, Mehta SR, Díaz R, Gerstein HC, Afzal R, Xavier D et al. Differential clinical outcomes associated with hypoglycemia and hyperglycemia in acute myocardial infarction. Circulation. 2009 Dec 15;120(24):2429-37. http://dx.doi.org/10.1161/CIRCULATIONAHA.108.837765 PMID:19948980

16. Goto A, Arah OA, Goto M, Terauchi Y, Noda M. Severe hypoglycaemia and cardiovascular disease: systematic review and meta-analysis with bias analysis. BMJ. 2013 Jul 29;347:f4533. http://dx.doi.org/10.1136/bmj.f4533 PMID:23900314

17. American Diabetes Association. Defining and reporting hypoglycemia in diabetes. Diabetes Care. 2005 May;28(5):1245-9. http:// dx.doi.org/10.2337/diacare.28.5.1245 PMID:15855602

18. Diabetes Control and Complications Trial Research Group. Hypoglycemia in the diabetes control and complications trial. Diabetes. 1997 Feb;46(2):271-86. PMID: 900070

19. Diabetes Control and Complications Trial Research Group. The effect of intensive treatment of diabetes on the development and progression of long-term complications in insulin-dependent diabetes mellitus. N Engl J Med. 1993 Sep 30;1993(329):977-86. http://dx.doi.org/10.1056/NEJM199309303291401 PMID:8366922

20. Pramming S, Thorsteinsson B, Bendtson I, Binder C. Symptomatic hypoglycaemia in 411 type 1 diabetic patients. Diabet Med. 1991 Apr;8(3):217-22. http://dx.doi.org/10.1111/j.1464-5491.1991.tbo1575.x PMID:1828735

21. MacLeod KM, Hepburn DA, Frier BM. Frequency and morbidity of severe hypoglycaemia in insulin $\nabla$ treated diabetic patients. Diabet Med. 1993 Apr;10(3):238-45. http://dx.doi.org/10.1111/j.1464-5491.1993.tboo051.x PMID:8485955

22. ter Braak EW, Appelman AM, Van De Laak M, Stolk RP, van Haeften TW, Erkelens DW. Clinical characteristics of type 1 diabetic patients with and without severe hypoglycemia. Diabetes Care. 2000 Oct;23(10):1467-71. http://dx.doi.org/10.2337/diacare.23.10.1467 PMID:11023138

23. UK Hypoglycaemia Study Group. Risk of hypoglycaemia in types 1 and 2 diabetes: effects of treatment modalities and their duration. Diabetologia. 2007 Jun;50(6):1140-7. http://dx.doi.org/10.1007/s00125-007-0599-y PMID:17415551 
24. Kristensen PL, Hansen LS, Jespersen MJ, Pedersen-Bjergaard U, Beck-Nielsen H, Christiansen JS et al. Insulin analogues and severe hypoglycaemia in type 1 diabetes. Diabetes Res Clin Pract. 2012 Apr;96(1):17-23. http://dx.doi.org/10.1016/j.diabres.2011.10.046 PMID:22136722

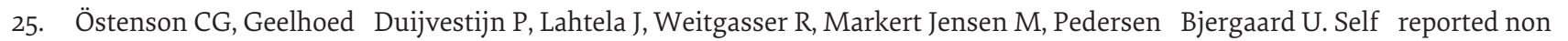
severe hypoglycaemic events in Europe. Diabet Med. 2014 Jan;31(1):92-101. http://dx.doi.org/10.1111/dme.12261 PMID:23796113

26. Donnelly LA, Morris AD, Frier BM, Ellis JD, Donnan PT, Durrant R et al. Frequency and predictors of hypoglycaemia in Type 1 and insulinవtreated Type 2 diabetes: a population\based study. Diabet Med. 2005 Jun;22(6):749-55. http://dx.doi.org/10.1111/ j.1464-5491.2005.01501.x PMID:15910627

27. Edridge CL, Dunkley AJ, Bodicoat DH, Rose TC, Gray LJ, Davies MJ et al. Prevalence and incidence of hypoglycaemia in people with Type 2 diabetes on oral therapies and insulin: a systematic review and meta-analysis of population based studies. PloS One. 2015 Jun 10;10(6):e0126427. http://dx.doi.org/10.1371/journal.pone.0126427 PMID:26061690

28. Waugh N, Cummins E, Royle P, Clar C, Marien M, Richter B et al. Newer agents for blood glucose control in type 2 diabetes: systematic review and economic evaluation. Health Technol Assess. 2010 Jul;14(36):1-248. http://dx.doi.org/10.3310/hta14360 PMID:20646668

29. Shyangdan DS, Royle P, Clar C, Sharma P, Waugh N, Snaith A. Glucagon $\triangle$ like peptide analogues for type 2 diabetes mellitus. Cochrane Database Syst Rev. 2011 Oct 5;(10):CDoo6423. http://dx.doi.org/10.1002/14651858.CDoo6423.pub2 PMID:21975753

30. Richter B, Bandeira $\triangle E$ chtler E, Bergerhoff K, Lerch C. Dipeptidyl peptidase 44 (DPP 44 ) inhibitors for type 2 diabetes mellitus. Cochrane Database Syst Rev. 2008 Apr 16;(2):CDo06739. http://dx.doi.org/10.1002/14651858.CDoo6739.pub2 PMID: 18425967

31. Swinnen SG, Simon AC, Holleman F, Hoekstra JB, DeVries JH. Insulin detemir versus insulin glargine for type 2 diabetes mellitus. Cochrane Database Syst Rev. 2011 Jul 6;(7):CDoo6383. http://dx.doi.org/10.1002/14651858.CDoo6383.pub2 PMID:21735405

32. Elliott L, Fidler C, Ditchfield A, Stissing T. Hypoglycemia event rates: a comparison between real-world data and randomized controlled trial populations in insulin-treated diabetes. Diabetes Ther. 2016 Mar;7(1):45-6o. http://dx.doi.org/10.1007/s13300-0160157-Z PMID:26886441

33. Allen KV, Frier BM. Nocturnal hypoglycemia: clinical manifestations and therapeutic strategies toward prevention. Endocrine Practice. 2003 Nov-Dec;9(6):530-43. http://dx.doi.org/10.4158/EP.9.6.530 PMID:14715482

34. Pedersen $\triangle B$ Bergaard U, Pramming S, Heller SR, Wallace TM, Rasmussen ÅK, Jørgensen HV et al. Severe hypoglycaemia in 1076 adult patients with type 1 diabetes: influence of risk markers and selection. Diabetes Metab Res Rev. 2004 Nov-Dec;20(6):47986. http://dx.doi.org/10.1002/dmrr.482 PMID:15386817

35. King P, Kong MF, Parkin H, Macdonald IA, Tattersall RB. Well-being, cerebral function, and physical fatigue after nocturnal hypoglycemia in IDDM. Diabetes Care. 1998 Mar;21(3):341-5. http://dx.doi.org/10.2337/diacare.21.3.341 PMID:9540013

36. Diabetes Research in Children Network (DirecNet) Study Group. Impact of exercise on overnight glycemic control in children with type 1 diabetes mellitus. J Pediatr. 2005 Oct;147(4):528-34. http://dx.doi.org/10.1016/j.jpeds.2005.04.065 PMID:16227041

37. Koltin D, Daneman D. 'Deadవinవbed'syndrome-a diabetes nightmare. Pediatr Diabetes. 2008 Oct;9(5):504-7. http://dx.doi. org/10.1111/j.1399-5448.2008.00404.x PMID:18503499

38. Akram K, PedersenषBjergaard U, Carstensen B, BorchषJohnsen K, Thorsteinsson B. Frequency and risk factors of severe hypoglycaemia in insulin $\nabla$ treated type 2 diabetes: a cross $\unrhd$ sectional survey. Diabet Medicine. 2006 Jul;23(7):750-6. http://dx.doi. org/10.1111/j.1464-5491.2006.01880.x PMID:16842479

39. Elwen FR, Huskinson A, Clapham L, Bottomley MJ, Heller SR, James C et al. An observational study of patient characteristics and mortality following hypoglycemia in the community. BMJ Open Diabetes Res Care. 2015 Jun 30;3(1):eoooog4 http://dx.doi. org/10.1136/bmjdrc-2015-000094 PMID:26157583

40. Böttcher J, Kunze A, Kurrat C, Schmidt P, Hagemann G, Witte OW et al. Localized reversible reduction of apparent diffusion coefficient in transient hypoglycemia-induced hemiparesis. Stroke. 2005 Mar;36(3):E20-2. http://dx.doi.org/10.1161/01. STR.0000155733.65215.C2 PMID:15692119

41. Cordonnier C, Oppenheim C, Lamy C, Meder JF, Mas JL. Serial diffusion and perfusion-weighted MR in transient hypoglycemia. Neurology. 2005 Jul 12:65(1):175. http://dx.doi.org/10.1212/01.wnl.0000167128.14769.7b PMID:16009922

42. Feinkohl I, Aung PP, Keller M, Robertson CM, Morling JR, McLachlan S et al. Edinburgh Type 2 Diabetes Study (ET2DS) Investigators. Severe hypoglycemia and cognitive decline in older people with type 2 diabetes: the Edinburgh type 2 diabetes study. Diabetes Care. 2014 Feb;37(2):507-15. http://dx.doi.org/10.2337/dc13-1384. PMID:24103900

43. Seaquist ER, Anderson J, Childs B, Cryer P, Dagogo-Jack S, Fish L et al. Hypoglycemia and diabetes: a report of a workgroup of the American Diabetes Association and the Endocrine Society. Diabetes Care. 2013 May;36(5):1384-95. http://dx.doi.org/10.2337/ dc12-2480 PMID:23589542

44. Bertoni AG, Krop JS, Anderson GF, Brancati FL. Diabetes-related morbidity and mortality in a national sample of US elders. Diabetes Care. 2002 Mar;25(3):471-5. http://dx.doi.org/10.2337/diacare.25.3.471 PMID:11874932

45. Abdelhafiz AH, Rodríguez-Mañas L, Morley JE, Sinclair AJ. Hypoglycemia in older people-a less well recognized risk factor for frailty. Aging Dis. 2015 Mar 10;6(2):156-67. http://dx.doi.org/10.14336/AD.2014.0330 PMID:25821643

46. Abdelhafiz AH, Sinclair AJ. Hypoglycaemia in residential care homes. Br J Gen Pract. 2009 Jan;59(558):49-50. http://dx.doi. org/10.3399/bjgpogX394860 PMID:19105916

47. Wild D, von Maltzahn R, Brohan E, Christensen T, Clauson P, Gonder-Frederick L. A critical review of the literature on fear of hypoglycemia in diabetes: implications for diabetes management and patient education. Patient Educ Couns. 2007 Sep;68(1):10-5. https://doi.org/10.14496/dia.6104869430.5 PMID:17582726 